This article was downloaded by: [University of Aberdeen]

On: 22 June 2011

Access details: Access Details: [subscription number 773500141]

Publisher Routledge

Informa Ltd Registered in England and Wales Registered Number: 1072954 Registered office: Mortimer House, 3741 Mortimer Street, London W1T 3JH, UK

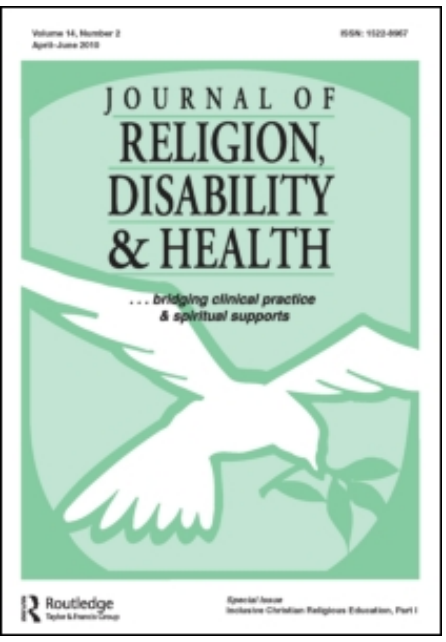

Journal of Religion, Disability \& Health

Publication details, including instructions for authors and subscription information:

http://www.informaworld.com/smpp/title content=t792306952

\title{
Whose Story Am I? Redescribing Profound Intellectual Disability in the Kingdom of God
}

John Swinton ${ }^{\mathrm{a}}$; Harriet Mowat ${ }^{\mathrm{b}}$; Susannah Baines ${ }^{\mathrm{b}}$

${ }^{\mathrm{a}}$ University of Aberdeen, Aberdeen, Scotland ${ }^{\mathrm{b}}$ Centre for Spirituality Health and Healing, University

of Aberdeen, Aberdeen, Scotland

Online publication date: 23 February 2011

To cite this Article Swinton, John, Mowat, Harriet and Baines, Susannah(2011) 'Whose Story Am I? Redescribing Profound Intellectual Disability in the Kingdom of God', Journal of Religion, Disability \& Health, 15: 1, 5 - 19

To link to this Article: DOI: $10.1080 / 15228967.2011 .539337$

URL: http://dx.doi.org/10.1080/15228967.2011.539337

\section{PLEASE SCROLL DOWN FOR ARTICLE}

\footnotetext{
Full terms and conditions of use: http://www.informaworld.com/terms-and-conditions-of-access.pdf

This article may be used for research, teaching and private study purposes. Any substantial or systematic reproduction, re-distribution, re-selling, loan or sub-licensing, systematic supply or distribution in any form to anyone is expressly forbidden.

The publisher does not give any warranty express or implied or make any representation that the contents will be complete or accurate or up to date. The accuracy of any instructions, formulae and drug doses should be independently verified with primary sources. The publisher shall not be liable for any loss, actions, claims, proceedings, demand or costs or damages whatsoever or howsoever caused arising directly or indirectly in connection with or arising out of the use of this material.
} 


\title{
Whose Story Am I? Redescribing Profound Intellectual Disability in the Kingdom of God
}

\author{
JOHN SWINTON \\ University of Aberdeen, Aberdeen, Scotland \\ HARRIET MOWAT and SUSANNAH BAINES \\ Centre for Spirituality Health and Healing, University of Aberdeen, Aberdeen, Scotland
}

\begin{abstract}
This article reflects theologically on the spiritual lives of people with profound intellectual disabilities. It offers a fresh way of exploring the theological contribution that such life experiences have for an understanding of God, human being, and what it means to be a church. By meditating on the storied nature of human beings, this discussion offers a narrative mode of resistance that seeks to develop powerful counternarratives that stand as a challenge to the "normal" stories told about people with profound intellectual disabilities. The discussion examines key questions around what it means to know God even when, intellectually, one might not know anything about God.
\end{abstract}

KEYWORDS qualitative research, theological reflection, profound intellectual disabilities, narratives, church, theological anthropology

Over the past few years the University of Aberdeen's Centre for Spirituality, Health and Disability (available at: www.abdn.ac.uk/cshad) has developed a unique program of action-oriented research that has sought to explore the role of spirituality in the lives of people with intellectual disabilities. All of the Center's projects have two key dimensions:

1. They are participatory in emphasis. The primary goal is to create research methods and approaches that incorporate and enable people with

Address correspondence to Reverend Professor John Swinton, School of Divinity, History and Philosophy, King's College University of Aberdeen, Aberdeen AB24 3UB, United Kingdom. E-mail: j.swinton@abdn.ac.uk 
intellectual disabilities to participate in the research process at every level from design to analysis.

2. All of the projects are action oriented-the interest is in generating new knowledge that will change practice.

The project that forms the core of this discussion is based on a method derived from person-centered planning and is focused on reflecting theologically on the lives of people who have profound intellectual disabilities with high support needs. ${ }^{1}$ Here some provisional thoughts are shared that have emerged from the time spent with people with profound intellectual disabilities, their families, caretakers, and support workers over the past 18 months. $^{2}$ Perhaps the best way to view what this discussion offers is to see it as a series of extended meditations on the lives of some real people and the issues that they bring to the table as theological conversations develop. As we reflect together on their experiences, so we will find ourselves challenged to rethink some important theological questions and perhaps even to change.

\section{WHOSE STORY AM I?}

The title of this article provides an interesting question to begin with. All of us live in a complex matrix of narratives and counternarratives that merge together, sometimes coherently, sometimes quite incoherently, to give us a sense of who we are and why we are in the world. In terms of personal identity, there is a real sense that we are the stories we tell about ourselves and about one another. But we are also the stories that others tell about us. Precisely who accurately tells your story? Is it you? Is it your family? Is it the government? Is it the church? It is of course all of these groups of people. Our lives comprise of a constant stream of narrative negotiations as we try to work out who we are and how we should act in and on the world.

This process of narrative telling and negotiating becomes problematic within the lives of people with profound intellectual disabilities, that is, people who, at least in terms of communicative capacity, are limited in their ability to narrate their own stories. Maybe a better way to put it is that they are limited by the communicational contexts within which they are embedded. As such they find themselves unable to narrate their own stories without the assistance of groups of people all of whom may misunderstand their stories and who frequently tell stories about the person that are different, contradictory and sometimes untrue. People with profound intellectual disabilities can easily become the victims of constructions of their stories that they do not own. The problem for people with profound intellectual disabilities is that they are limited in their opportunities to develop narratives of resistance, that is, counternarratives that will stand against oppressive or 
misleading stories that others tell about their lives and which will bring about active transformation. Counternarratives do the work of repairing broken or misleading narratives and as such become a place of rupture and change. Counternarratives offer a point of resistance. This discussion examines how, together, we might work towards developing such counternarratives of resistance and explore what it might mean to listen carefully and transformatively to those who have no words.

\section{PERSONHOOD}

Let us begin with an apparently passing comment by the mother of one young man with a profound intellectual disability. Brian is 36 years old. He has no language and does not communicate through any formal system of communication (at least any known system). We had spent a couple of hours talking about Brian with his mother, his caretakers and various other support workers, trying to work out precisely what his spiritual needs might look like. At the end of this process Brian's mother said, "It's been lovely to talk about Brian. Since I can't talk to him, talking about him is good. He's a good person." She did not of course mean that she literally could not talk to Brian. She spoke with him all the time, even though it was not at all clear how much Brian could understand and whether his responses related to their immediate encounter. (I can think of a few of my theology students to whom the same observation could be made!) Her point was that he was limited in his ability to respond to her and that she had actually learned a lot about him by listening to the various stories that people had told about him. But what is interesting in her statement is the way that she positions Brian as "a good person."

\section{POSITIONING AND RECOGNIZING}

Psychologist Romme Harré has developed what has come to be known as positioning theory (Harré \& Langenhove, 1999). Positioning theory is an alternative way to read and to understand the dynamics of human relationships. Harré criticizes standard notions of role as being overly static, disembodied, and paying little attention to specific contexts. Roles describe typical social positions such as husband, wife, banker, typist, for example. However, they fail to identify the particularities of the experience of a person who is ascribed a particular role. Knowing that a person has the role of wife tells one very little about what it means for you as a named person to be a wife. Positioning theory offers a more dynamic perspective than role theory, focusing on the special position of a particular individual within an encounter. This position is communicated through language. The way in which we 
position a person within a relationship will determine how we respond to her. What we see in Brian's mother's statement is her positioning him within their relationship in a quite specific way. Cultural narratives may commonly position Brian as disabled, unable to communicate; a tragic figure; his mother linguistically positions him as "a good person" and in so doing offers a simple but powerful counternarrative that gives Brian a quite different story. Despite his disability, despite the apparent negativity of his situation, Brian's mother tells a story that positions him as a good person-just as he is.

So what we have embedded within this situation and spoken out in deceptively simple language are two radically different stories that can be told around Brian's life. One is the common cultural story that provides the context for Brian's life beyond his home. This story constructs him as a tragic figure, emphasizing loss, tragedy, and deficit. The other is told by his mother who brings another story to the table, a counternarrative that emerges from a series of counternarratives presented by his caretakers and support workers that reflect the goodness of Brian's life. Whose story is Brian? I want us to keep that dynamic of narrative and counternarrative in mind as we move on.

\section{HEALING DOWN SYNDROME}

Derek is another person with whom we work in our current project. Derek is 60 years old. He has significant sight impairment and limited communicational skills. People also say that he has Down syndrome. In our interviews with his caretakers and support workers, one of his support workers told us a story about another man with Down syndrome, Ian, who had recently died. Ian had been taken to the mortuary and laid out. When the care worker had gone to see Ian's body, he noticed that there was absolutely no sign of Down syndrome! Even the telltale lines on his hands had (apparently miraculously) disappeared. The caretaker spoke to the undertaker who did not know that Ian had Down syndrome. Others noticed this. One person was spooked. The caretaker put it this way: "Where Ian is, he'll not have Down syndrome because he'll have a resurrection body."

Whose story is Ian? What theological story is being told about Ian and by implication about Derek and everyone who has Down syndrome? He'll not have Down syndrome because be'll have a resurrection body. That resurrection body no longer has Down syndrome. The lines on Ian's hands have vanished! Now, he is "like us." In other words the resurrection body is perceived to be the body of an able bodied person no longer burdened by genetic difference. But why would this be considered a good thing? What exactly does God think is wrong with Down syndrome that it is not to be represented in the resurrection body? What does it say about the value of Ian and Derek's bodies now, in the present, if they are to be transformed or perhaps even 'healed' in the eschaton? What exactly would be healed? Who 
would Ian be in this new and alien body? Would such a "miracle" really be encouraging for people with Down syndrome now, in the present?

Such a story makes sense when told from the perspective of a medical model which is often reflected in common cultural assumptions of beauty and perfection, but does it actually make theological sense? The apostle Paul observes that the resurrection body has both continuity and discontinuity with our present bodies ( 1 Cor $15, \mathrm{NLV}){ }^{3}$ In other words our bodies are transformed not replaced. Each body will be changed in the resurrection, and each body will in some sense remain the same! Why would we assume that Ian or Derek's bodies will be transformed into the shape of a body without Down syndrome has no continuity with the body they had?

But, and this is important, as soon as that story was told, Jean, Brian's close friend and caretaker was asked what her dreams for Brian might be. She replied, "My dream for Brian is that he'll always be Brian and allowed to be Brian." How interesting ... allowed to be Brian." Brian cannot be allowed to be Brian if the primary theological story we tell about him requires that he is changed into something different when he dies; something closer to what we see ourselves to be and what we imagine the norm will be in heaven. Is it not more likely that the lines on Ian's hands which caused him to acquire the label Down syndrome and all of the social stigma that accompanies such a label, will, like the scars of Jesus, accompany him to heaven, but without the negative assumptions and associations? ${ }^{4}$ Is not Margaret's simple but powerful counternarrative closer to the oft overlooked inference of Psalm 139 ?

For you formed my inmost being.

You knit me together in my mother's womb.

I will give thanks to you, for I am fearfully and wonderfully made. Your works are wonderful. My soul knows that very well.

My frame wasn't hidden from you, when I was made in secret, woven together in the depths of the earth.

Your eyes saw my body.

In your book they were all written, the days that were ordained for me, when as yet there were none of them (NIV).

Why would God only mould and shape able bodies?

\section{STORY-COUNTERSTORY-REDESCRIPTION: WHY (AT LEAST SOMETIMES) THE MEDICAL STORY MIGHT BE A GOOD THING}

One more example might help us understand the importance of the emerging pattern of story-counterstory-redescription. ${ }^{5}$ Those of us who are engaged in developing the theology of disability have long been involved in an ongoing 
critique of the medical model of disability (Swinton, 2001). I am convinced of course that many of our concerns are necessary and appropriate. However, in the midst of the polemic we need to be careful not to fail to recognize the importance of the medical story for the protections of people with disabilities. This excerpt from a conversation we had with the father of a young man, James, who has profound intellectual disabilities, is enlightening on this point:

People were telling us constantly that James could be healed in the sense [of being] spiritually healed to become emotionally whole and that basically it wasn't their fault that ... We had it once or twice that as it wasn't working it must be something in our lives that is not right. And we had it from the Catholic perspective too because I'm from a Catholic background and basically we were told it was because I wasn't in a Catholic marriage basically. Even though in the last generation I had an uncle I never knew that he died in his twenties... with needs very similar to James's. So it was in the family and I have mild cerebral palsy as well so there is obviously something there but that was ignored basically and they said it was obviously something me or Jane [my wife] or something we were doing that was causing Kieran not to be healed.

It is interesting to notice that in this story, it is the theological narrative that becomes profoundly negative and problematic within the lives of this family. It is the medical narrative that is the counternarrative that when told, alleviates guilt, offers a very different definition of the situation and enables people to see things quite differently. The counternarrative does not offer an alternative theological definition, it simply casts doubt on the story that the church was telling about James and in so doing opens a space for a new theological perspective to be developed. If we simply assume that the medical model provides an unredeemably negative story of disability we risk missing its potential for redescribing situations of disability in potentially positive ways. Perhaps the medical approach requires a degree of sanctification as well as criticism?

My point in focusing on these three instances of storytelling and counterstory-redescription is to begin to show how living alongside and listening carefully to the experiences of people with profound intellectual disabilities in ways that respond creatively and prophetically to the question: Whose story am I? might be of fundamental importance for the faithful living out of the gospel.

\section{THE STORIED NATURE OF PERSONHOOD}

Of course, one might respond, "How can we possibly envisage a person with a profound intellectual disability writing their own story! It is inevitable 
that someone writes their story for them." The fact that we might find such a question credible is of course an indication of how immersed in modernity we have become. Only in modernity could we imagine it credible to perceive ourselves as self-narrators or to think that self-narration is a particularly good thing. Stanley Hauerwas (1999) noted:

\begin{abstract}
As Christians we know we have not been created to be "our own authors," to be autonomous. We are creatures. Dependency, not autonomy, is one of the ontological characteristics of our lives. That we are creatures, moreover is but a reminder that we are created with and for one another. We are not just accidentally communal, but we are such by necessity. We are not created to be alone ... For Christians the mentally handicapped [sic] do not present a peculiar challenge. That the mentally handicapped [sic] are constituted by narratives they have not chosen simply reveals the character of our lives (Swinton, 2001, p. 16).
\end{abstract}

True, people with profound intellectual disabilities may be vulnerable to constructions of their life stories that are negative and destructive. But that is so for all of us. None of us really tells or owns our stories. We are all people who are storied by a Creator God who resides within a narrative of creation, cross, and redemption that we can share in but can never own. Certainly we need to learn to tell that story well; or perhaps better to let that story tell us well. This is the essence of faithful discipleship. But even there we do not tell our stories on our own. Our stories are told as we learn to live well together in ways that recognize the strength of difference and the difference of strength within the coming Kingdom of God (1 Cor 1:18-31, NIV). It is this radical counternarrative that offers the possibility of redescribing the world in ways which honor, respect and listen to people who have no words but who have much to say.

\title{
REDESCRIBING PROFOUND INTELLECTUAL DISABILITY IN THE KINGDOM OF GOD: DISCOVERING DEPENDANT-INDEPENDENCE
}

\section{Beyond Autonomy?}

With these initial thoughts in mind, let us begin to think about what listening to the counterstories embodied within the lives of people with profound intellectual disabilities might look like. A useful place to begin is with the question of autonomy. Within liberal societies autonomy is assumed to be a primary social good. Put simply autonomy is self-sovereignty. Living autonomously means living by a law that you impose on yourself. The word autonomy comes from the Greek autos (meaning self) and nomos (meaning rule, governance, or law). Literally autonomy means being governed by one's self. In autonomy, the self becomes its own sovereign. Put slightly 
differently, autonomy is the right to live your own life in your own way. At one level, the types of people I have been describing thus far can never be autonomous. However, as we have seen, what is true for them turns out to be true for all of us. Full autonomy is an illusion. So does this mean that the idea of autonomy is meaningless or even dead? Perhaps, but maybe rather than rejection, what it requires is new content-content that emerges from our reflections on the lives of people with profound intellectual disabilities. Autonomy may be dead but resurrection is still possible! Autonomy may require a new story.

\section{Elizabeth and Mary}

Elizabeth is the key worker for Mary, a young woman with profound intellectual disabilities. Mary has cerebral palsy, speaks no language, and is blind. Elizabeth and Mary's mum have just arranged for Elizabeth to drive the family van, which means that on the weekends Elizabeth and Mary can go out and have fun together without Mum. This is very much a rite de passage for mum. The idea that Mary can have a social life out with Mum's social life is a new and radical counterstory that has been introduced into their lives via our research project. The old story was that Mary's life is Mum's life and vice versa. The new story is that Elizabeth and Mary can be friends without mum. Elizabeth provides in her young woman caring role the transitional object for Mary. ${ }^{6}$ As Mary's advocate and friend, Elizabeth negotiates Mary into her different worlds. Through Elizabeth, Mary can become 21, different to her mother, and separate from her family.

By beginning to act as if Mary were moving from dependence to independence, it seems as though mum and Elizabeth are trying to find a way to honor Mary's passing into adulthood even though she still remains entirely dependent on them. That dependence will not change. But their approach to her can change. So they must negotiate her transition (tell new stories) for her, given that she cannot do so herself. In a family with no special needs (if, in fact, such a family exists?), the parent will gently push the child out into the world, making sure there is always a safe place back home if necessary. Usually much shouting and emotion accompanies this process! The child wants to go further; the parent tries to manage the departure. There are false starts, and recriminations. None of this is available to Mary in that form. So mum's gift to Mary is to mark her transitions; Elizabeth's gift to Mary is her friendship. Might it then be the case that a person can be completely dependent, yet treated as independent as a form of respect for their personhood? ${ }^{7}$ Might our natural state be one of dependent-independence? Autonomy then would be based on relationships and would be required for and intended to enhance relationality. ${ }^{8}$ Autonomy could then be perceived as a gift given in relationship. We need one another in order to be autonomous and to sustain autonomy. 
It seems to me that the strivings of Elizabeth and Mary's mum to actualize Mary's dependant-independence is in some senses paradigmatic of what it means to be a creature before God. We are completely dependent upon God; yet, in order to function faithfully and fulfill our vocation we need to develop independence that is nonetheless based on dependence. We need to become dependently independent. ${ }^{9}$ The key, for Christians, is not to forget our core dependency as we strive to develop our independence. The tragedy of modernity is the way in which it has confused the story of dependant-independence with the story of unfettered freedom. In a most interesting way, Elizabeth, Mary and Mary's mother remind us of our true situation. But Mary has more to say.

\section{SPIRITUALITY AND COMMUNITY: TWO STORIES}

\section{Sharing in Silence}

Mary lies on the floor when out of her chair or bed on a massage mat, which also makes a musical noise. She has no speech but makes sounds. She has muscle spasms continuously. She has limited vision but her hearing is excellent. She cannot feed herself and she is entirely dependent on her caretakers for all her physical needs. Mary is a Quaker. She was made a member of that community when she was a baby. Quakers understand the significance of silence. ${ }^{10}$ In the service, Mary shouts noisily. She shouts and sometimes lets out long rather winsome wails. However, as the community moves into times of silence, Mary becomes silent. As the silence of the community engulfs the room, so Mary shares in the silence. Precisely what that silence means is unclear; but her response is regular ... patterned ... engaged.

\section{Sharing in Emotions}

Several years ago Mary was diagnosed with leukemia. Her mother told us of the moment Mary was informed of the diagnosis. Mother was deeply upset. She said to Mary "You have leukemia." Mary became deeply upset. She wept.

\section{The Communal Nature of Spirituality}

Now what is going on in these two stories? It is probably unlikely that Mary understood the words, "You have leukemia." But who is to say? My interpretation certainly should not trump mum's, who assumes that Mary understood perfectly well. ${ }^{11}$ But, assuming for a moment that the story I am telling about Mary contains at least some truth, it seems that she is a deeply sensitive 
young woman who picks up on subtleties in communication, emotion and mood. When she was being told the news of her illness, she picked up on mum's emotions and wept with her in response to the rhythms of mum's sadness. She did not understand the words but she did understand the feelings and the experience of sadness.

In the context of Quaker worship, a similar thing seems to be happening; she is sharing in the atmosphere-the feelings emotions and mood of the meeting. Her spirituality is being formed and held by her participation in the community. Mary's spirituality is not simply something she alone has. It is not a feeling or an emotion that is simply within her. It is something she shares in; it is an experience that rises beyond her; an experience that happens in the space between the members of the community: the space of meeting. She is dependent on her community for her spiritual experience. If that is the case, then Mary's spirituality is a corporate rather than personal concept and experience. This is a slightly startling counternarrative to contemporary understandings of spirituality that perceive it to be a personal thing that is located firmly within the desires and the control of the individual. Mary's experience seems to indicate that spirituality may be a corporate event within which a person is greatly dependent on others. If this is so for Mary, then might it be so for all of us? Such a revelation should not really surprise us particularly bearing in mind the apostle Paul's words: Don't you realize that all of you together are the temple of God and that the Spirit of God lives in you? (1 Cor 3:16 NLT (emphasis added).

\section{Knowing God}

For Mary, her relationships and her spirituality are inextricably interlinked. I imagine, now she has helped us to notice it, what is so for Mary is so for all of us. To notice the relational and corporate nature of spirituality is no small point. ${ }^{12}$ A deeper reflection takes us to the very heart of faith and the most profound question: How do we know God? Many of us are used to assuming that spirituality is a personal thing. Likewise, we are used to assuming that knowing God is primarily a personal thing and often times as much an intellectual rather than a relational thing. For many, to know God is to know and to understand and proclaim the name of Jesus. But what if we cannot understand and proclaim the name of Jesus, at least not in conventional ways? Mary's story offers us a powerful counternarrative. Spirituality is something that we have together. I am spiritual because we are. Likewise she challenges us to think about whether the ways we think we know God are in fact as adequate as we assume them to be. Is knowledge of God really individual knowledge or do we always and necessarily know God primarily and perhaps only in community? Knowledge of God could therefore be personal in the sense that it relates to the individual person 
understood in the ways I have outlined that concept previously, but not individualistic in the sense of something that lies out with community. Does our dependant-independence then even stretch to our relationships with God?

Think about it this way. We cannot touch God; we do not normally hear God (at least not directly); we do not feel God. So precisely what does knowing God mean? It is quite a different thing to know about God than it is to know God, so presumably being an expert in Scripture and theology does not guarantee that you know God in any kind of meaningful or salvific way. This being so, precisely what do typical people (that is, people who conform to the accepted norm of intellectual ability and who communicate and understand in "typical" ways), claim to know that Mary does not? The incarnation teaches us that God comes to us in friendship and accommodates to our needs quite apart from anything that we might have to offer (Swinton, 2000; 2007). So we know God not through what we have discovered via our own efforts but simply and only because God has made himself known to us in Jesus. But where is Jesus? Matthew 25 tells us that Jesus is in the poor, the sick, the hungry, those whom society chooses to describe as strangers. Indeed a failure to recognize this fact is a criterion for Divine rejection. Does Jesus have to be named to be ministered to? Apparently not. In other words, Jesus is encountered in compassionate relationships particularly, but not exclusively as they are acted out in reference to the outcast and the stranger. To know God is to do justice ${ }^{13}$ That being so, it would appear that knowing Jesus is a relational concept and not merely an intellectual one. We know Jesus as we encounter Jesus through the Holy Spirit in and through one another (1 Cor 6:19-20, NLV).

God is love ( 1 John 4:8, NLV). Love is not an attribute of God, it is an ontological statement about what and who God is. But bow do we know what love looks like? The answer? Through our relationships, our family, our associates, our friendships. We cannot learn what loves looks like unless it is embodied in action. Love is therefore an embodied relational act that we receive from one another; as we receive it we learn what love looks like and feels like and ultimately what it is. As we discover what love feels like so we begin to understand what it means to know, love and be loved by God. That love stems of course, from the Divine gift of friendship given to us in Christ (Reinders, 2008; Swinton, 2000). However, none of us can understand anything of what that might mean until it is embodied in the relationships, which somehow and however inadequately, seek to manifest that gift. Even those who, through the use of their intellect and reason, recognize something of the origins of that gift don't really have any knowledge of God apart from that which God has chosen to reveal to them. It is all gift.

If then Jesus is, in whatever sense, within us, and if our relationships are the place where we learn what love looks and feels like, then Christian friendships are a place where we physically encounter God. That being 
so, Mary's relationships within her community not only hold and sustain her spirituality (and she theirs), they are also the place where she encounters God in tangible ways. Her relationships are holy places where God is revealed, or better, where God reveals God's self to her. Likewise, accepting Mary's smiles, her touch, her sensitivity, her love is a way of receiving God's love. Does God's love have to be named for it to be experienced? The practical and biblical evidence seems to suggest otherwise.

\section{CONCLUSION}

It seems then that the art of listening to and telling counterstories reveals the heart of the gospel. It is only as we slow down and take the time to be with one another; only as we come close enough really to listen and respect one another that we learn to tell one another's stories well. Such listening and storytelling includes the ways in which we listen to and tell the story of God. And of course, the place where we learn such listening is in our friendships; our Christ-like friendships that are extended to one another Gracefully according to the principle of the incarnation (Swinton, 2000). God in Jesus enters into friendships with human beings who are radically unlike God's self. In so doing God lays down a principle of grace that forms the pattern for friendships that claim to be genuinely Christian; friendships that reach towards, embrace and are embraced by those whom society considers to be least like "us." In so doing the incarnation is radically lived out and becomes an enduring presence in the lives of the people of God as they live lives that anticipate the coming Kingdom.

The problem of course is that Mary has no friends. No one has marked out and chosen Mary to be their friend. Well, that is not strictly true. Elizabeth is genuinely Mary's friend. But Elizabeth is paid to be Mary's friend ${ }^{14}$ Is that the basis for friendships we are called to develop within God's coming Kingdom? It may be part of the story, but it cannot be the whole story. Surely it is an adequate response to Mary for her to find herself in a position where the only people she is friendly with are those who are paid to be with her? Where can Mary find a friend who will tell her story well? I do not mean to leave things on a negative note. Quite the opposite, I think the challenge is profoundly positive. It seems to me that one way to describe discipleship is this: Disciples are those friends of Jesus who are charged to live out and to tell different stories about the world. Mary is a disciple. If you think that is a problematic statement I would be interested to know why? Perhaps the question to end with is this: Who will help to write, tell and live Mary's story with ber? In answering that question we might just discover that we need Mary more than we think she needs us. 


\section{NOTES}

1. The term high-support needs signifies people who have a profound intellectual disability, which includes high support needs and communication difficulties that present major challenges to having one's views and preferences heard and understood.

2. The project that forms the core of the qualitative data presented in this article is funded by the Arts and Humanities Council in the United Kingdom and titled: Understanding the Spiritual Lives of People with Profound and Complex Learning Disabilities: A Community-Oriented Action Research Approach. (available at: http://abdn.ac.uk/cshad/LDproject.htm) The intention of the project is to find out more about the spiritual lives and needs of people with profound learning disabilities who have limited or no verbal language with which to communicate and to develop strategies and approaches designed to meet such needs.

3. For a further exposition of the nature of heaven and the resurrection body, see Wright (2008). Wright's focus is not on disability, but his arguments have clear resonances for the theology of disability.

4. For a deeper reflection on such a suggestion but with a focus specifically on physical disability see Eiesland (1995). For discussion on this point with a particular focus on intellectual disability, see Yong (2007). For a counterperspective to Yong's view, see Brock (2009).

5. I use the term redescription in like manner to Walter Brueggemann's (2008) usage of the term. Brueggemann asks the question: What are we doing when we read the bible? The answer he proposes is that what we are doing in Scripture study, reading and hearing is redescribing the world. His thesis is that human existence, society, and culture are necessarily socially constructed. We are guided in our interpretative processes by a variety of scripts that we use to define and make sense of the world. Powerful as these defining scripts may be, the church is called to live by a different script: the script that emerges from "the strange new world within the Bible" and the radical redescription of reality that this world provides. The task of theology is to engage in a process of constructing the reality of the world differently-redescribing it in the light of Scripture. The act of redescription functions to "protest against the initial description and to insist that the initial presentation of reality is not an adequate or trustworthy account." (Brueggemann 2006) Such redescription does not merely seek to mirror the world, but rather provides a complementary critical perspective wherein God is perceived as creatively present in the processes of life. Thus "every time the church takes up Scripture, it undertakes a serious challenge to dominant characterizations of our social world. It dares to propose an alternative reading of the world, an alternative version that is in fact a sub-version that rests beneath the dominant version in a less aggressive form." (Brueggemann 2009, p. 4).

6. A transitional object is something that takes the place of the mother during the process of moving from dependency/symbiosis to separation (Winnicott, 1953). It seemed clear that Elizabeth was functioning in this way and that her role as a "young woman" positioned her as a place of transition that marked the seeds of a psychological separation from Mary and her mother. Of course, that separation is more psychological than physical but its transitional function seemed clear (see Kunz [2010] in this issue for a development of this idea of transitional objects.)

7. The analogy between human freedom and Divine sovereignty is apparent at this point.

8. It is as we engage in relationships that we discover who we are. Relationships are thus seen to be foundational to how we understand ourselves. Identity comes from encounter rather than through autonomy or self-reflection. As we encounter one another so also we bestow identity and value, or otherwise, on one another.

9. If this is the case, then perhaps it gives an insight into what personhood is. Might it be the case that, rather than being a set of attributes or common criterion that we have to meet, human personhood is in fact a gift that we bestow upon one another through our friendships and ultimately through Divine friendship? Might the issue be not what makes a person a person but, as Mcfarland (2001) has argued, who makes a person a person?

10. For a very helpful theological reflection on silence, see Gillibrand (2010, 66-67).

11. The issue here is the somewhat controversial area of perception. In a fascinating book, $A$ World Without Words David Goode (1994) relates the results of his 2-year long interaction with two deaf and dumb children with profound intellectual disabilities. Goode shows that even the most profoundly disabled individuals are able to communicate, to respond, and to experience emotions. The key is to come close and re-learn that which culture has taught one to ignore or misunderstand. Important for current purposes is Goode's observation that there was often a tension between what happened in a school context and what happened in the home. The professionals and the educators could not see the types 
of communicative interaction that Goode and the family saw. Goode puts this down, not to inaccurate parental perception and reporting, but rather to the failure of professionals to adequately understand the empirical details of everyday family life. The professionals trended to put such attributions of thinking down to delusional or pathological interpretations by parents. Goode argues, however, that it is crucial to note that irrespective of whether people with such severe disabilities can understand and think as other people do, professional assessments stand no greater claim to truth than the assessments of the nondisabled people. "It is true that while professional assessments may carry more authority or political weight in determining the life circumstances of people with disabilities, there is no reason to consider them more accurate in an absolute sense or any less a reflection of social definitions and perspectives... clinical and medical bodies of knowledge cannot be used to provide a standard by which to judge the legitimacy of family belief systems. Clinical perspectives are based on different ways of knowing and seeing than the perspectives of people involved in intimate relationships with those who have disabilities" (Bogdan \& Taylor, 1989, p. 141). With this in mind I am more than a little wary of ascribing a lack of thinking or ability to Mary.

12. See Kunz (2010) in this issue for a similar reflection on the communal nature of religion.

13. " 'He defended the cause of the poor and needy, and so all went well. Is that not what it means to know me?' declares the LORD" (Jeremiah 22:16, NLV).

14. My point here is not that there is necessarily a problem with paid friendship, only that it is not what most of us would choose to have.

\section{REFERENCES}

Bogdan, R., \& Taylor, S. J. (1989). Relationships with severely disabled people: The social construction of humanness. Social Problems, 36, 135-148.

Brock, B. (2009). Autism, care and Christian hope. Journal of Religion, Disability $\varepsilon$ Health, 13(1), 7-28.

Brueggemann, W. (2006). The Word that redescribes the world: The Bible and discipleship. Minneapolis, MN: Augsberg Fortress.

Brueggemann, W. (2009). Redescribing reality: What we do when we read the Bible. London: SCM.

Eiesland, N. (1995). The disabled God. Nashville, TN: Abingdon.

Gillibrand, J. (2010). Disabled church-disabled society: The implications of autism for philosophy, theology and politics. London, UK: Jessica Kingsley.

Goode, D. (1994). A world without words. In The social construction of children born deaf and blind (pp. 7-46). Philadelphia, PA: Temple University Press.

Harré, R., \& Langenhove, L., van (1999). Positioning theory. Oxford, UK: Blackwell. Hauerwas, S. (1999). Timeful Friends: Living with the handicapped. In S. Hauerwas (Ed.), Sanctify them in the truth: Holiness exemplified (pp. 143-156). Nashville, TN: Abingdon.

Mcfarland, I. (2001). Difference and identity: A theological anthropology. Cleveland, $\mathrm{OH}$ : Pilgrim.

Reinders, H. (2008). Receiving the gift of friendship: Profound disability, theological anthropology and ethics. Grand Rapids, MI: Eerdmans.

Swinton, J. (2000). Resurrecting the person: Friendship and the care of people with severe mental health problems. Nashville, TN: Abingdon.

Swinton, J. (2001). Spirituality and mental health care: Rediscovering a "forgotten" dimension. London, UK: Jessica Kingsley.

Swinton, J. (2004). Critical reflections on Stanley Hauerwas' theology of disability: Disabling society, enabling theology. Binghamton, NY: Haworth Pastoral Press. 
Swinton, J. (2007). Raging with compassion: Pastoral responses to the problem of evil. Grand Rapids, MI: Eerdmans.

Winnicott, D. (1953). Transitional objects and transitional phenomena. International Journal of Psychoanalysis, 34, 89-97.

Wright, N. T. (2008). Surprised by hope: Rethinking Heaven, the Resurrection, and the mission of the Church. New York, NY: Harper Paperbacks.

Yong, A. (2007). Theology and Down syndrome: Reimagining disability in late modernity, Waco, TX: Baylor University Press. 